\title{
The SWOT Analysis and Countermeasures for the Development of the New Energy Vehicle Industry in China
}

\author{
Chunyan Qu \\ Economic Management Department \\ Changchun University of Technology \\ Changchun,China \\ 1049976696@qq.com
}

\author{
Tianhe $\mathrm{Zu}$ \\ Software Engineering \\ Changchun University of Technology \\ Changchun, China \\ 1278277877@qq.com
}

\begin{abstract}
Under the pressure of environmental and energy issues, the development of new energy vehicles is a general trend. China attaches great importance to the event of new energy vehicles. After 20 years, the combination of production and learning, demonstrate and operation have made the new energy vehicles achieved remarkable results in $R \& D$ and have made considerable development. Based on the analysis of SWOT, this article will put forward the countermeasures and suggestions for the development of China's new energy auto industry from the perspectives of development model and policy based on the analysis of China's new energy auto industry's growth of competitive advantage, competitive disadvantage, opportunity and threat.
\end{abstract}

Keywords—new energy vehicle; SWOT analysis; development model; competition

\section{The Connotation of New Energy Vehicles}

The concept of new energy vehicles first appeared in the 1960s and was first proposed in the 863 plan in the early XI period in China. New energy vehicles can be divided into generalized new energy vehicles and narrow new energy vehicles. Generalized new energy vehicles, also known as alternative fuel vehicles, include fuel cell electric vehicles and pure electric vehicles, all of which use non-petroleum fuel. They also include non-petroleum fuel vehicles such as hybrid electric vehicles and ethanol gasoline cars. The current concept consists of all new energy vehicles, which are divided into the following categories: pure electric vehicles, hybrid cars, alcohol ether fuel vehicles, fuel cell vehicles, and natural gas vehicles. The narrow new energy vehicles refers to the use of unconventional vehicle fuel as a source of power, comprehensive control of the vehicle's power and drive advanced technologies, the formation of new technology, new structure, advanced technology, the car. According to this concept, new energy vehicles include pure electric vehicles, hybrid vehicles, fuel cell vehicles, alcohol ether vehicles, and gas vehicles.[1]

\section{The SWOT ANalysis for the Development of NeW ENERGY VEHICLE INDUSTRY IN CHINA}

\section{A. The analysis of competitive advantage}

1) It has rich advantages in the rare resources needed for the development of the new energy automobile industry.

China's lithium reserves are very rich, ranking third in the world. Lithium-ion power batteries are the mainstream choice for automotive power batteries. In China, the raw materials for electric motors and the source of electric vehicle batteries are also vibrant. Iron, manganese, silver, rare earth, permanent magnet materials, phosphorus, etc. are also rich in resources. China's rare earth resource reserves are also very rich, ranking first in the world, permanent magnet materials must rely on lanthanum and other rare earth resources, and permanent magnet motor is the main component of durable magnet materials. Metal lithium, graphite, rare earth, and magnesium are the raw materials needed for new energy vehicles. These resources are abundant in China.

2) The advantages of the industrial environment.

China's institutional strengths have played a significant role in the further development of new energy technologies. It is conducive to the development of unified standards for charging equipment, power supply and connectors, which is beneficial to its application in the industry, and its efficiency is much higher than the developed countries in the West.

3) Having the advantages of advanced electric vehicle power system and vehicle integration technology. [2]

All along, the Chinese government has attached great importance to the development of the new energy automotive industry, has invested vast amounts of capital and has the support of policy, China's electric vehicle power system has its intellectual property rights, and the overall level of vehicle integration technology is at the leading position in the world.

4) It is relatively easy to have latecomer advantages.

Due to the relatively late start of China's traditional automotive industry compared to European and American countries, and the penetration rate of automobiles is low, so, the cost of China's industrial transformation is relatively small, and the development of new energy automobile industry has 
its latecomer advantages and it is relatively easy to upgrade the industrial structure.

\section{B. Analysis of Disadvantages}

\section{1) Disadvantages of core technologies.}

There is still a big gap between the core technologies of China's new energy vehicles and the multinational auto giants. The technology will not pass, but will directly lead to cost and quality problems. For example, the core technologies of our country's drive motor control system and battery management system are still not good enough.

\section{2) Lack of market awareness.}

China's work in the promotion of new energy vehicles is still not enough, there is only one way to popularize it, mainly depends on the government's policy orientation, we should further enhance consumer awareness of new energy vehicles, such as its credibility and safety, etc.

\section{3) Lack of supporting facilities.}

China's entire society still lacks the necessary facilities for the use and promotion of new energy vehicles.

\section{4) The disadvantage of resource integration.}

In the process of the development of new energy vehicles in China, there is very little cooperation between upstream and downstream enterprises. Each enterprise is independent of its own, lacking of government integration, resulting in decentralized resources, technology research and development are mostly repetitive, low-level, it not only Many research and development resources have not been appropriately configured, and they have not been able to break through technology fundamentally.

\section{Analysis of opportunities}

\section{1) It is opportunities for people's needs.}

In recent years, people's demands for the environment have become higher and higher, and the continuous rise in the price of oil has led people to consider energy issues and develop new energy vehicles.

\section{2) Potential market opportunities.}

China is a country with a large population in the world, but the vehicle ownership is relatively low, so the market potential of the car is still enormous. In full consideration of the characteristics of differentiation and diversification of China's auto consumers, it will become the consumer market further subdivided, and will continuously develop new types of new energy vehicles, which will gradually expand the market for new energy vehicles in China.

\section{3) It is opportunities for active policy support.}

National and local governments have played an active role in the development of new energy vehicles. In addition to increasing financial support for the new energy automotive industry, they have repeatedly issued policies and regulations to promote the development of new energy vehicles.

\section{Threat Analysis}

1) The threat of local protectionism.

Although local governments actively respond to the country's support for new energy vehicles, the development of new energy vehicles in the region has often restricted the entry of new energy vehicles in the other areas and limited their growth.

\section{2) The threat of alternatives.}

China's new energy auto market is still not mature enough. [3]It is in its early stage. The characteristic of this stage is that the capital investment is very large, but the profit is very low and even there will be losses. Therefore, many companies are still more inclined to compete in the traditional car market and production, which can quickly bring immediate rewards

3) The threat of international auto giants.

The global auto giants have significant advantages in core technologies. They set up research and development institutions in the automotive market in China, developed many models of new energy vehicles, and carried out vigorous publicity and promotion, realizing high-volume sales. However, the overall strength of our country is relatively weak, and there is almost no enterprise that can compete with it.

\section{COUNTERMEASURES AND SUGgESTIONS FOR THE Development of ChInA's New EnERgy Automobile INDUSTRY}

\section{A. Countermeasures and Suggestions for the Development Mode of the New Energy Vehicle Industry in China}

1) The innovation of new energy supply model to improve the profitability of new energy automotive industry.

The most significant difference between traditional automobiles and new energy vehicles is the demand for energy. The use of new energy vehicles will generate power supply problems for batteries and batteries, while ordinary cars are not needed. This problem leads to high profits. At present, the major problem faced by new energy vehicles is that the charging time is long, and it usually takes 5 to 6 hours to charge. Consumers think this is inconvenient. Therefore, it is necessary for charging operators to change the traditional charging methods and concentrate the batteries. Management, recycling, and maintenance ensure that when consumers need to recharge the battery, they can directly exchange the charged battery in the charging station, and then continue to open the way. This is new energy supply mode, namely the battery rental mode. This model can allow consumers to wait for a long time, and consumers also can pay according to the amount of electricity used because the difference between oil and power is relatively significant so that consumers can save a lot of costs. This model is not only It is only beneficial to consumers, and it can attract many investors to invest in, broaden their business types, target individuals for personalized marketing, improve the efficiency and quality of services, and reduce operating costs, under a vast, profitable space. Battery management and power supply market will gradually mature, new energy vehicle demand and value huge improvements. 
2) Improve the construction of corresponding supporting facilities.

At present, the obstacle to the development of the new energy automobile industry is that the relevant, necessary supporting facilities such as charging piles are not perfect. At present, buses are the dominant models of new energy vehicles. Charging piles are mainly used to provide services for buses. Charging stations that are specially used to charge buses at public transportation stations can be opened to the public and can be converted into buses that can be used to load buses. Electricity can also be used as a place for charging private cars. The bus group pays for the power consumed by the coach and privately swipes the electricity consumed by the individual consumer. With the continuous increase in the number of electric vehicles, only the transformation of bus stations cannot satisfy more consumers, and it can reconstruct the parking spots where the parked cars in a centralized manner, such as existing parking lots in shopping malls, parking lots, and community parking lots. The parking lot under construction or to be constructed must incorporate the charging facility construction into the construction plan. The charging fee and parking fee are different, and payment is made using credit card payment. Consumers can request the private parking garages. The new energy vehicle suppliers that they purchased will build the charging piles and provide the necessary power from their circuits.

3) Breaking the technical bottleneck and strengthening the cooperation between the industrial chain.

The research and development of core technologies for new energy vehicles involve chemical, mechanical, material, and energy technologies.[4] However, breakthroughs in technological bottlenecks require cooperation between the entire industry chain. It is not sufficient for companies to rely on themselves. Auto manufacturers focus on R\&D of core technologies. Put more money into it. At the same time, all parties involved in energy companies, financial institutions, core parts and components companies, university research institutes, and infrastructure providers must strengthen cooperation and invest together to save R\&D costs and share the fruits of technological development. Moreover, not only must strengthen cooperation between domestic industry chains, but also use international high-tech achievements to strengthen international exchanges and cooperation, to achieve a breakthrough in bottleneck technology and better develop new energy vehicles.

4) Business model innovation to meet the personalized market demand.

The main technical problem of new energy vehicles is the length of the cruising range. The long cruising range will make new energy vehicles more convenient to use, but in this way, prices and use costs are also very high. Companies can produce new energy vehicles with cruising range of $150 \mathrm{~km}$, $300 \mathrm{~km}$, and $400 \mathrm{~km}$, by the general travel schedule of private cars, taxis, and buses. For individual car buyers, cars are mainly used for work and daily driving. With a short distance, you can purchase new energy vehicles whose life is less than 150 kilometers. Such vehicles have a relatively small battery capacity and a relatively low cost. [5] The purchase price is similar to that of a traditional car, and young office workers are relatively easy to accept; for enterprises Units, bus companies, and taxi groups can use vehicles that have a range of more than 300 kilometers because their performance requirements are higher than the price. Only by refining the market to meet the individual needs of different consumers can the new energy auto market develop better and better.

\section{B. Countermeasures and Suggestions on China's New Energy Vehicle Development Supporting Policies}

1) Defining the responsibilities of the policy and focusing on the spontaneous regulation of the market

Whether it is an emerging market or a mature market, it should follow the rules of its development, and the government cannot intervene too much. It is impossible to popularize the new energy automobile market in a short period. Only with continuous improvement of technology and supporting facilities, plug-in hybrid vehicles and pure electric vehicles can develop. Hybrid cars are the excess of traditional car models to new energy car models. The automatic adjustment of the market has led many car companies to promote them. The government should also provide strong support. Policies must not only innovate in technology but also provide support and encouragement to organizations and institutions that carry out technological research and development. Also, the government can use subsidies and tax exemptions to stimulate consumer spending. The government should allow the market to give full play to its regulatory role. In this way, it is more conducive to enterprises to continuously improve the services of new energy vehicles, so that the new energy vehicle market will continue to mature.

\section{2) Increase social propaganda}

In China, the development of new energy vehicles is relatively late, people's awareness of environmental protection is not yet active, and consumers' awareness of the environment is still insufficient. The government should strengthen publicity and education on environmental protection knowledge so that people can recognize that electric vehicles have improved the environment. Benefit. Youth can be more publicized and educated to cultivate potential consumers. For example, Japan often displays new energy vehicles in community-sponsored events. It also allows people to experience it personally and writes relevant knowledge about new energy vehicles in textbooks so that young people can learn. These measures are worthy of our country's reference. The Chinese government can also use TV, newspapers, WeChat, and the Internet to promote environmental protection knowledge.

\section{3) Improve the management of patented technology}

Many related technologies for new energy vehicles are still under research and development. The State Intellectual Property Office should set up a licensed database specifically to regulate the management of patients for the development of drive motors, batteries and complete vehicles. Through an indepth analysis of the database to find the lack of core technology in China to increase research and development, learn from successful international patents, independent innovation. Individual personnel shall be assigned to manage the patented technology database, and the core technology 
patents that have just been developed and applied for shall be entered promptly, and an analytical report of professionals may be provided to the automobile enterprises. Also, for the implementation of new energy components and new energy vehicle export-oriented enterprises, before product exports, it should be clear about the similar patent situation in the importing country, to avoid patents; the product was seized, causing legal disputes.

\section{CONCLUSION}

The new energy vehicle is the development direction of the automobile industry in the future. With the increasing awareness of environmental protection and the aggravation of energy crisis, the development of new energy vehicles is getting more and more attention. At present, the development of new energy vehicles in China should break the situation of mainly relying on government subsidies, and strive to establish a multi-party participation, multi-benefit mechanism of construction, operation and maintenance, in order to promote the sustainable development of the industry.

\section{REFERENCES}

[1] China Automotive Technology and Research Center, "China's New Energy Vehicle Industry Development Report Reports (2014) Beijing: Social Sciences Academic Press, 2014

[2] Wang Zhanglin, Li Guofu, Zhang Fang, “Consummation of China's New Energy Vehicle Industry Policy in the Perspective of Intellectual Property Rights”, Journal of Dalian Maritime University (Social Sciences Edition), 2014.

[3] Jingjing Yang, Research on Hunan Energy Industry Development [J]. Chinese Foreign Investment. 2014(01).

[4] Guo Lihua, Chen Liming. Discussion on China's New Energy Industry Investment Fund Model [J]. Economic Research Guide. 2014(1): 127128.

[5] Xu Aiping, The dilemma of the development of the industrialization of new energy vehicles in our country and the solution to it[J]. Theoretical Sphere. 2015(7):28-33. 